\title{
Analysing the Welfare Impacts of an RTA Between China and Nigeria
}

\author{
Musa Talba Jibrin \\ Department of Economics, University of Maiduguri, Maiduguri, Nigeria
}

Email address:

mtdjibir@gmail.com

\section{To cite this article:}

Musa Talba Jibrin. Analysing the Welfare Impacts of an RTA Between China and Nigeria. Journal of World Economic Research. Vol. 10, No. 1, 2021, pp. 10-17. doi: 10.11648/j.jwer.20211001.12

Received: January 1, 2021; Accepted: January 13, 2021; Published: January 28, 2021

\begin{abstract}
Regional trade agreement is a tool for economic integration between two or more nations. It takes several forms and there exists different types of agreements depending of its purpose. Just like any trade blocks it has advantages and shortfalls especially if the trading partners are not natural partners. Regional Trade Agreements (otherwise known as RTA) yield welfare benefits in form of consumer surplus, trade creation, revenue and income to the trading partners This paper analyses the welfare impacts of a possible RTA between Nigeria and China. There is huge trade flow between the two countries The major commodities traded and covered in this paper include fuels, machineries and transport. equipment and chemicals. Using data sourced mainly from the World Integrated Trade Solutions (Comtrade, WTO/IDB, WTO/CTS) the paper uses descriptive statistics in measuring the welfare impacts of the agreement The paper reveals that Nigeria possess a Revealed Comparative Advantage (RCA) of export of fuels to China while China possess an RCA of textile, clothing and foot wears export. Its further reveals that if the two economies could focus on trade in the goods with highest RCA, trade will be created and welfare achieved. More so, the RTA leads to deep economic integration. The paper recommends Nigeria and China should hasten the signing of RTA agreement for mutual benefits.
\end{abstract}

Keywords: Revealed Comparative Advantage (RCA), RTA, Welfare and Consumer Surplus, Trade Creation, Trade Diversion

\section{Introduction}

Trade occurs between two or more partners in order to exchange goods, services and to optimize gain from trade. The literature on the rationale behind trade and forming of trade blocks varies over time and space. The first generation of trade economists argue that a nation or country should only trade in goods it has absolute advantages and that given a packages of rigid assumptions such as factor mobility within national boundaries only has created a big push on the new thinking of trade theory postulation,

The paradigm shift takes into consideration the importance of Intra-industry trade (IIT) both vertical and horizontal and that welfare consequences arise from the new growth theory also known as endogenous growth models. They simply postulate the existence of linkage between productivity and trade. (i.e productivity-trade links).

The main objective of this paper is to analyze the impacts of a Regional Trade Agreements between Nigeria and China.
The specific objectives are to:

i. Determine the evolution of Nigeria and China Trade over time

ii. Examine the trade openness in the two economies

iii. Extract and interpret tariff barriers to trade in the two countries

iv. Know the major trading partners of China and Nigeria and identify the top five major products exported and imported in the two economies

v. Interpret geographical distribution and sectoral composition of Nigeria's trade

vi. Compute the RCA and IIT

The paper is divided into three sections. Following the introduction is a brief literature review then methodology will be last section, 


\section{Literature Review}

Trade liberalization such as removal of tariff and non-tariff measures is welfare enhancing. Scholars such as Baldwin and Wyplosz [1], Dasgupta and Panagariya [2], Cecchini et al. [3], Evans et al.[4], Gasiorek et al. [5], Grossman and Helpman [6], Grubel and Lloyd [7], Humphrey and Schmitz [8], Cox and Harris [9], Krugman and Venables [10], LaNassa [11], Smith and Venables [12], UNSD Comtrade [13], UNCTAD [14] and Winters [15] all agree with this assertion. All are convinced on the welfare impacts of RTA. The bond of contention here is what make trade beneficial and what matters. Is it having abundant resources that matter or promoting trade and economic relations. The literature has documented that both of the above mentioned are key to achieving welfare benefits. Although there is no silver bullet (one size fits all) one thing we are sure of from liberalisation or integration is economy wide benefits. A healthy economic space need to be created where exchange takes place within countries, and between industries abiding by the rules and agreements signed at the floor of WTO and timely peaceful arbitration between member nations.

What is paramount in materializing and broadening the gains from trade agreements and its welfare dimensions is the specialization and forming the right trade blocks between and within countries. Trade - productivity nexus gains could also be galvanized intra firms and industry must be promoted to be able to quickly catch up with the trade stimulis.

\section{Methodology}

There is myriad of standards methods for assessing changes in trade policy. These methods range from simple linear regression, descriptive statistics, computable general equilibrium methods and partial equilibrium analysis. Each has its own unique feature, advantages as well as disadvantages.

The university of Sussex framework has come with a framework and model to overcome some methodology limitations and very adequate in explain the deep and shallow integration phenomena. Thus this paper uses same framework of action.

\subsection{Source of Data}

Data for this paper are mainly sourced from the:

1. World Integrated Trade Solutions

2. United Nations Statistical Division Commodity Trade

3. World Trade Organization Integrated Databases

4. World Trade Organization Consolidated Tariff Schedules Databases and

5. And National Bureau of Statistics of the two countries

\subsection{Analytical Tools}

Data were analyzed using:

1. Descriptive statistics

2. Regression and correlation analyses

3. Non parametric statistics

\section{Results and Discussion}

One of the first things one notes from the figure 1 above is the trade deficit Nigeria is running; imports seem to be growing at a faster pace than exports, which shows a widening trend for the budget deficit. This has been largely reported by the literature and in recent years has been largely due to imports from China. The year 2000 is followed by the upward trend in import and decline in export.

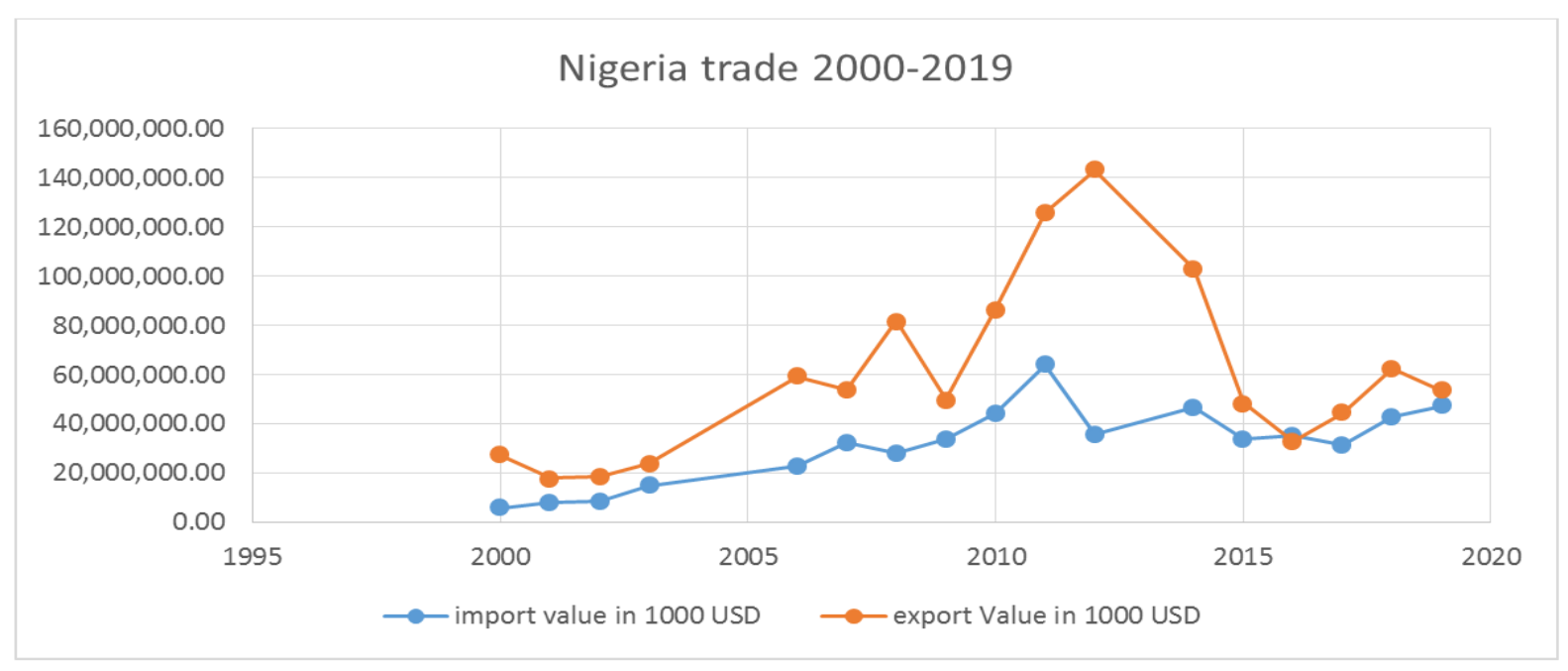

Source: Author's computation, 2020.

Figure 1. Evolution of Nigeria's trade in time, 2000 - 2018 (in US dollars). 


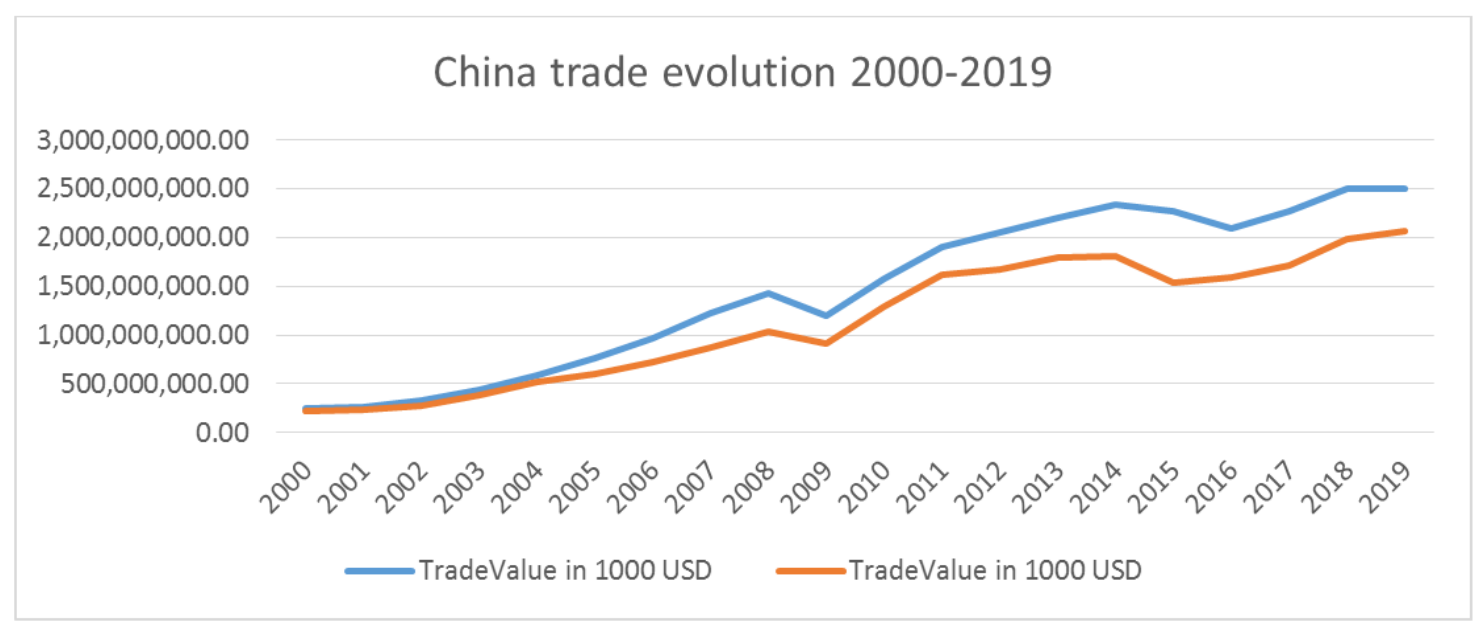

Source: Author's computation from Comtrade Data source, 2020.

Figure 2. Trend of Chinese trade in time from 2000-2019 (in US dollars).

China seems to have a more trade surplus account with import and export balance in the year 2000.

Looking at the measures of trade openness (Measure of openness is calculated as the proportion of trade (imports plus exports) over real gross domestic product we can assert that China seems more to trade than Nigeria.

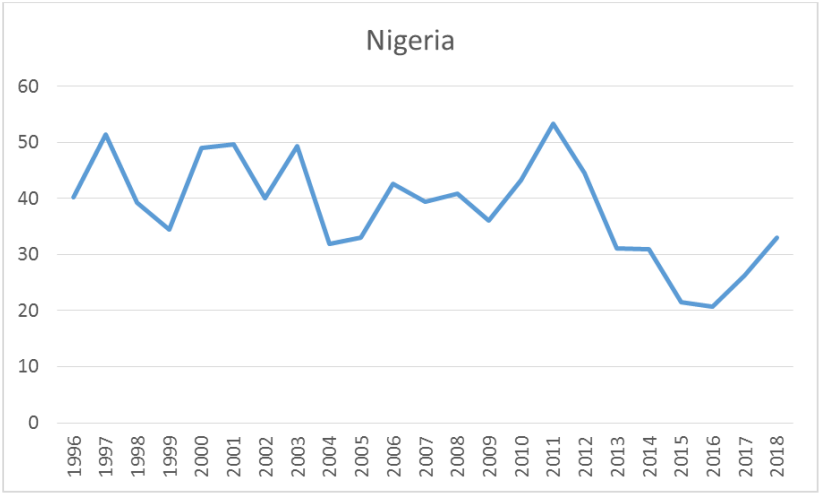

Source: Author's computation, 2020.

Figure 3. Nigeria openness, 1996-2018.

Trade openness in Nigeria seems to have maintained same pace since 1996. It was at $40 \%$ in 1996 , before rising to $50 \%$ in 1997. From 1998 till 2011 the openness is slightly similar and settled at 50\%. But in 2015 due to major structural shocks it has fallen to $20 \%$ and remained so till 2017 . It is currently at $30 \%$ of GDP.

China trade seems to be more opened over the period under analysis. For example in 2006 Nigeria openness vis a vis China is $40 \%$ and $60 \%$ respectively. This shows that China is more opened to trade than Nigeria.

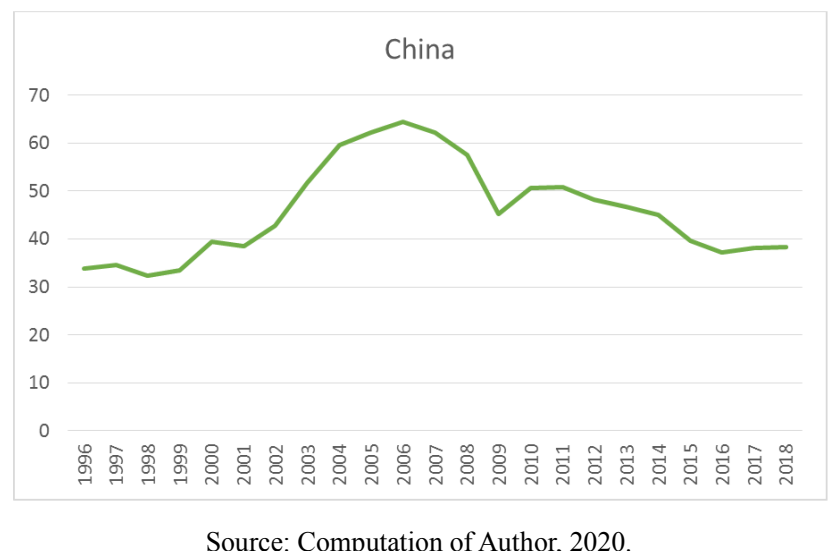

Source: Computation of Author, 2020.

Figure 4. China Openness to Trade.

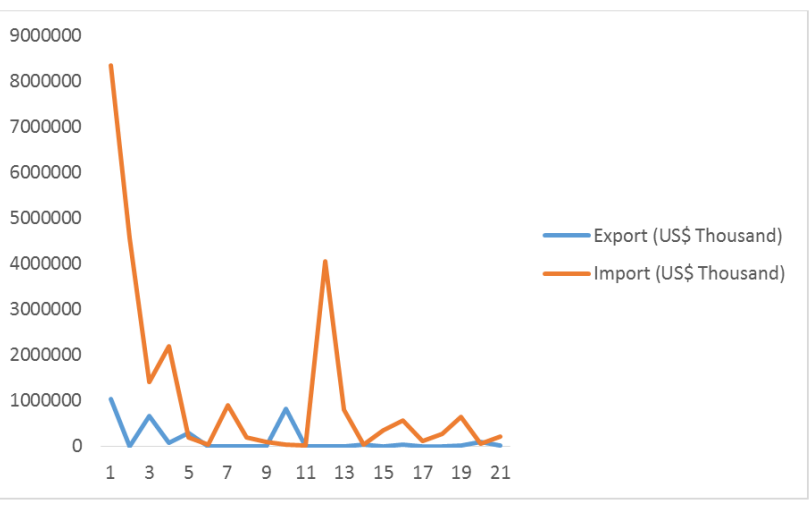

Source: Author's calculations, 2020.

Figure 5. Nigeria's trade with China, 2000 - 2019 (in millions of US dollars).

Table 1. Nigeria's average tariffs by Broad Economic Classifications (From 1997 to 2019).

\begin{tabular}{|c|c|c|c|c|c|c|c|c|c|c|}
\hline & 1997 & 2001 & 2006 & 2008 & 2011 & 2014 & 2015 & 2017 & 2018 & 2019 \\
\hline Food and beverages & 27.39 & 26.22 & 15.78 & 15.69 & 14.91 & 14.91 & 14.91 & 14.98 & 14,34 & 11.65 \\
\hline Industrial supplies not elsewhere specified & 13.84 & 8.04 & 7.99 & 7.91 & 7.49 & 7.27 & 7.28 & 7.65 & 6.66 & 6.66 \\
\hline Fuels and lubricants & 7.45 & 7.20 & 4.96 & 4.34 & 4.17 & 4.00 & 4.56 & 5.58 & 5.09 & 5.07 \\
\hline
\end{tabular}




\begin{tabular}{|c|c|c|c|c|c|c|c|c|c|c|}
\hline & 1997 & 2001 & 2006 & 2008 & 2011 & 2014 & 2015 & 2017 & 2018 & 2019 \\
\hline Capital goods (except transport equipment) & 13.40 & 12.86 & 7.54 & 7.29 & 7.38 & 7.17 & 7.21 & 7.48 & 7.23 & 6.19 \\
\hline Transport equipment and parts and accessories & 21.94 & 20.08 & 11.08 & 11.60 & 11.55 & 11.02 & 11.08 & 11.07 & 11.07 & 9.21 \\
\hline Consumer goods not elsewhere specified & 25.86 & 21.71 & 14,35 & 13.37 & 13.96 & 13.91 & 13.96 & 14.48 & 14.39 & 7.03 \\
\hline Goods not elsewhere specified & 11.78 & 10.09 & 14.35 & 13.87 & 13.96 & 9.48 & 9.48 & 14.48 & 9.41 & 9.36 \\
\hline Total & 6.95 & 6.93 & 6.30 & 6.04 & 5.62 & 4.42 & 4.36 & 4.27 & 4.18 & 4.18 \\
\hline
\end{tabular}

Source: World Integrated Trade Solutions, 2020.

AS can be seen Nigeria deficit is not less important compared with China with a relatively wider deficits.

Here, we can say very little about the welfare impacts that may arise from a possible RTA (Regional Trade Agreement between Nigeria and China). We can opine that the more these two trading partners relate with each other and with the rest of the world, the greater the scope

We can authoritatively assert that the higher the trading volumes between the two economies the more likely is the deepness of integration and more welfare. We need to investigate the tariff structure in order to ascertain the dimension of the welfare effects as follows.

\subsection{Computation of Tariff Barriers to Trade}

One of the fundamental steps in computing possible trade gains emerging from one of the first steps in computing the bilateral trade relations is to assess the tariff structure of the country analyzed. By implication higher tariff means trade diversion and low tariff implies possibly a consumer surplus and more integration.

Table 2. China average unweighted MFN tariffs by BEC sector China average tariffs (unweighted), 1999-2019 by BEC category.

\begin{tabular}{lllll}
\hline & $\mathbf{1 9 9 9}$ & $\mathbf{2 0 0 6}$ & $\mathbf{2 0 1 1}$ & $\mathbf{2 0 1 9}$ \\
\hline Food and beverages & 30.00 & 9,44 & 11.40 & 12.79 \\
Industrial supplies not elsewhere specified & 7.40 & 8.00 & 6,54 & 5.77 \\
Fuels and lubricants & 9.00 & 3,27 & 4.18 & 3.87 \\
Capital goods & 15.50 & 6.42 & 6.03 & 3.75 \\
Transport equipment & 20.01 & 13.03 & 11.66 & 14.17 \\
Consumer goods not elsewhere specified & 31.00 & 8.83 & 10.10 & 15.83 \\
Goods not elsewhere specified & 10.16 & 8,83 & 10.10 & 15.18 \\
\hline
\end{tabular}

Source: World Integrated Trade Solutions, Various Years.

Table 2 shows that the MFN tariffs have been decreasing continuously. The most significant decrease is in the food and beverages and consumer goods not specified sectors. The general MFN is of small magnitude. This implies that trade creation and trade diversion effects will also be of small magnitude. At this juncture it is not possible to determine which of the two magnitudes is high.

\subsection{Computing the Geographical Distribution of Nigeria's Trade}

The main export sector for Nigeria is the one delimited by the Standard International Trade Classifications (SITC revised 3) code entitled "mineral fuel/lubricants. All the eight Sectors are relatively stable and less volatile over the period under investigation.

With respect to import Nigeria's import shares by SITC rev 3 sectors, 1999-2019, capital goods and chemicals continue to take the lion share. We have also observed a signify ant reduction in the exports of mineral fuels and increase in the machinery/transport equipment.

This is indication that Nigeria's dependence of capital goods increase over time.

Having identified the main trading partners of Nigeria with the rest of the world we now analyze its trade with China by products group. The closer and similar are the trade composition between China and Nigeria the more beneficial a FTA is to them.

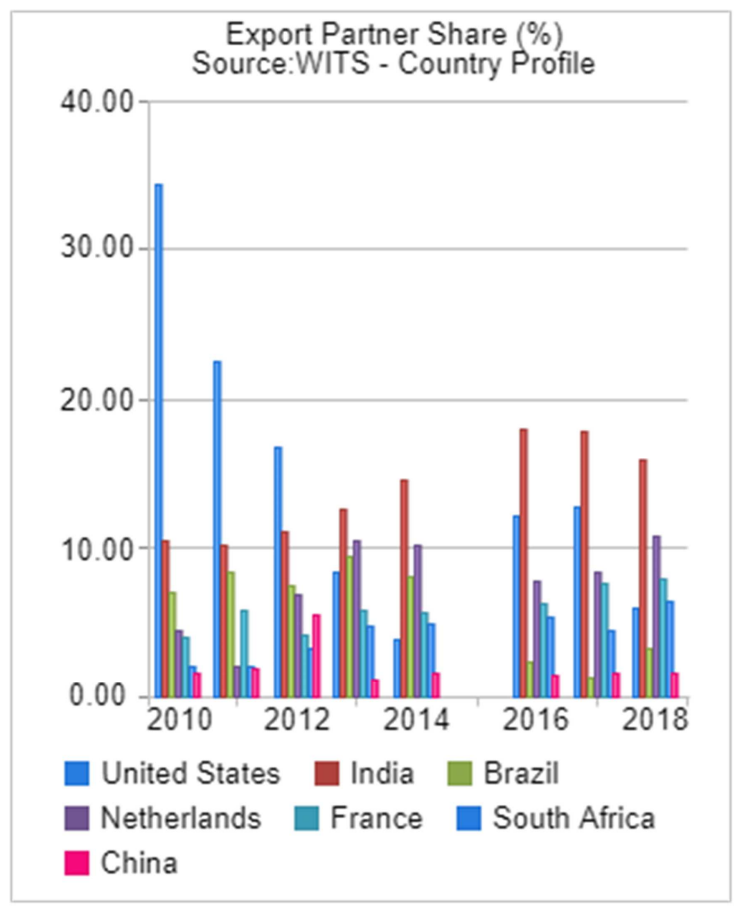

Source: Author's computation, 2020.

Figure 6. Nigeria export shares by main trading partner, 2010-2018. 


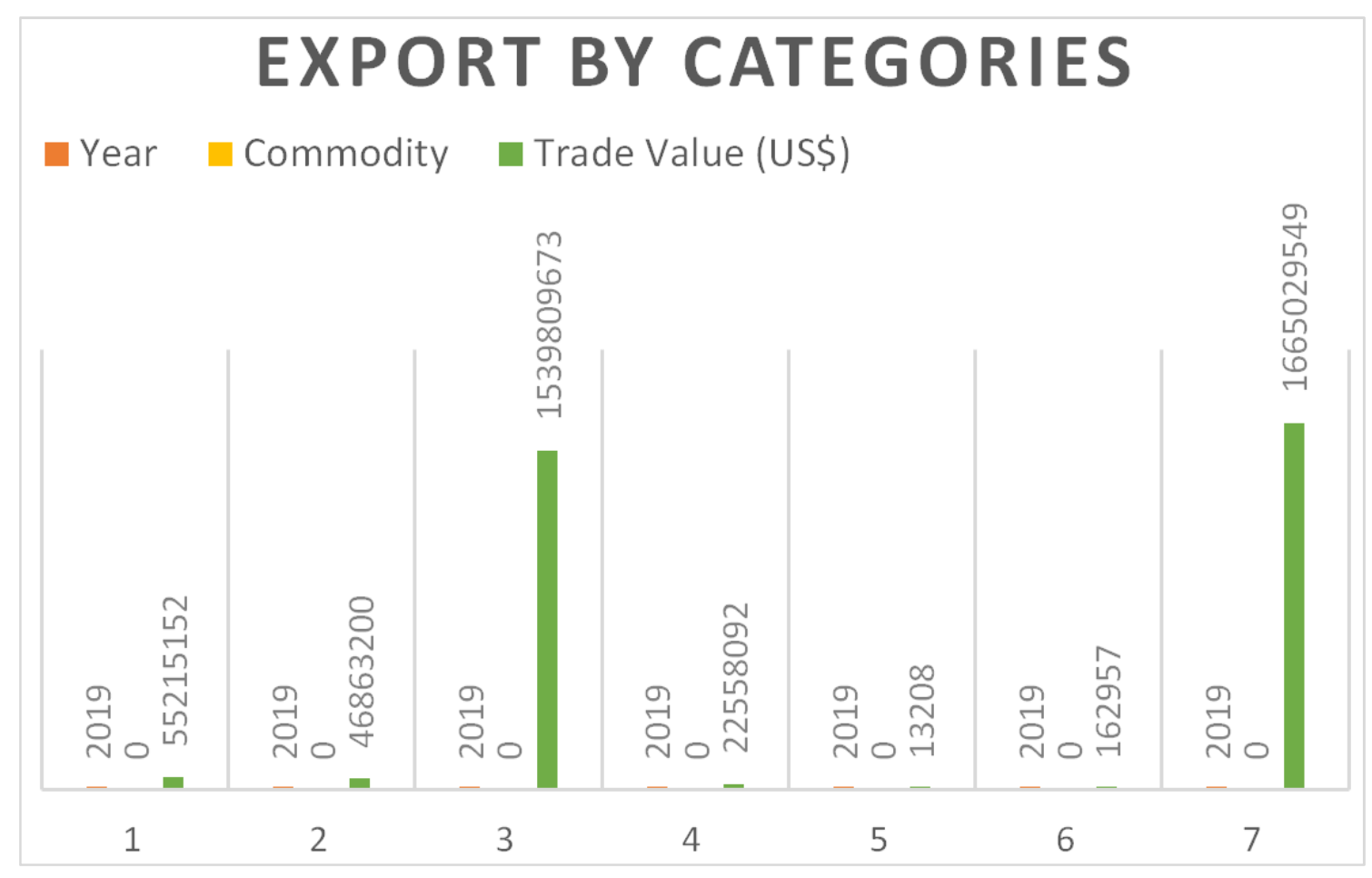

Source: Author's computation, 2020

Figure 7. Sectoral Composition of Nigeria's trade 1999-2012.

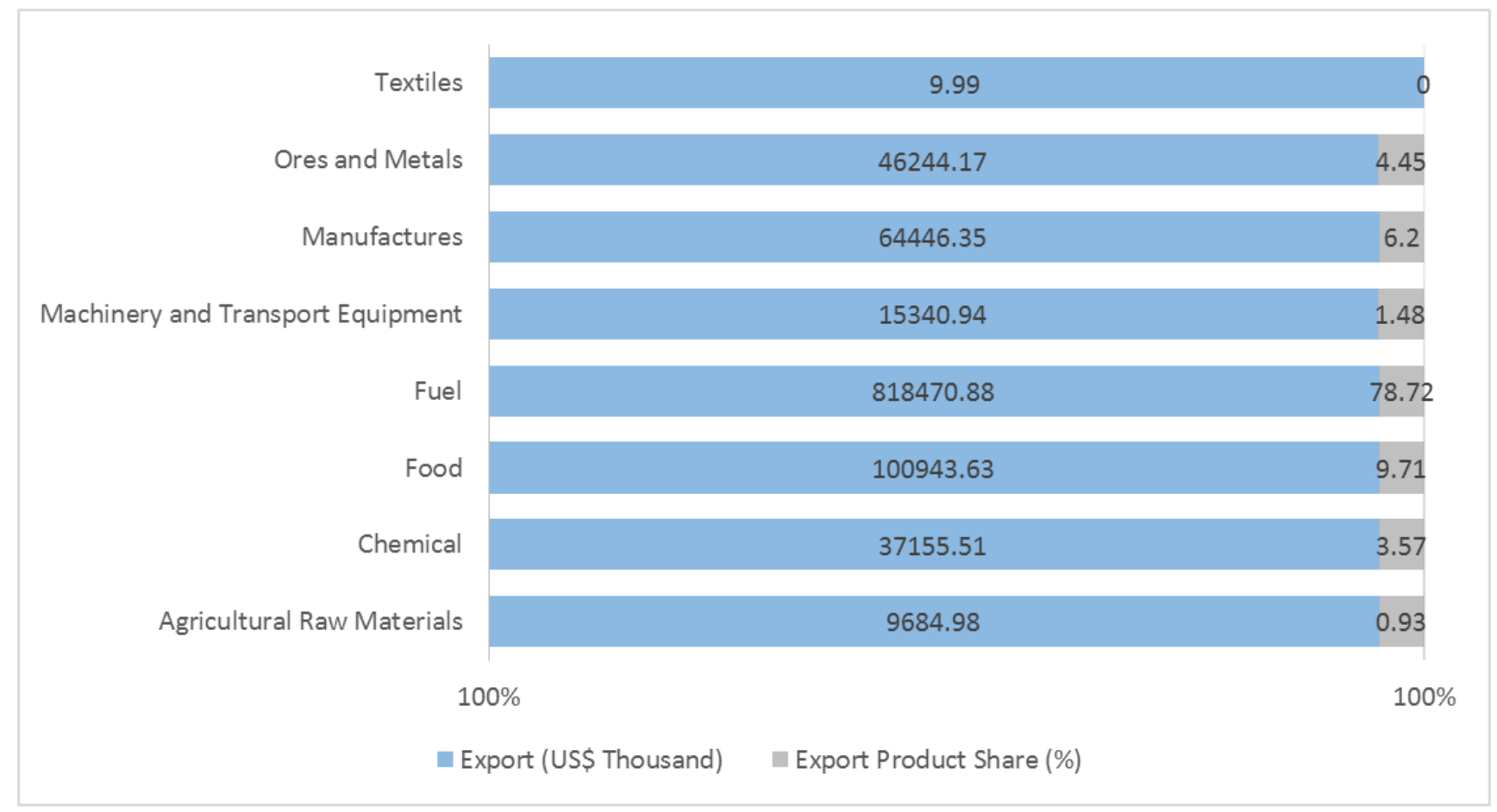

Source: Author's computation, 2020

Figure 8. Nigeria Export Share to China by SITC Rev 2, 2018.

A look at the figure above reveals that the composition of exports to China is dominated by exports of fuel but has witnessed a slight decrease. We now proceed to imports share China. 


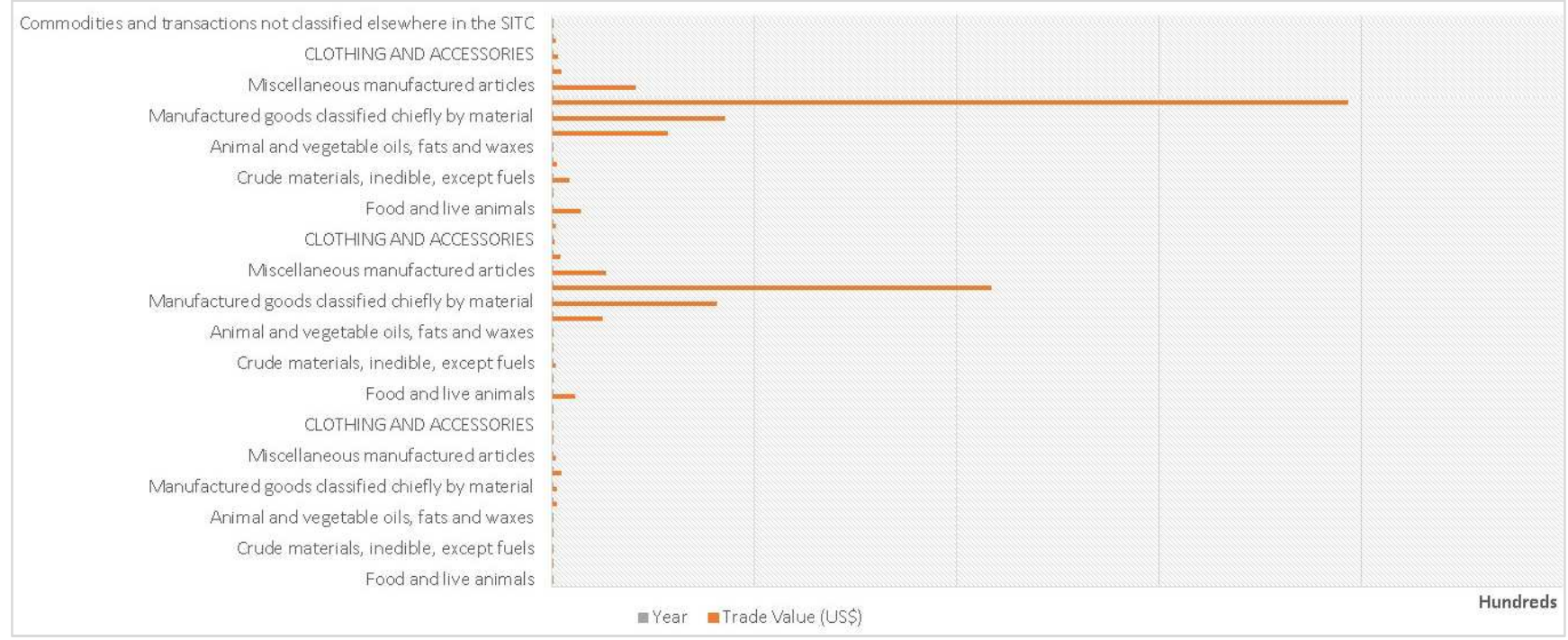

Figure 9. Nigeria imports share from China SITC rev 3 sectors, 2000, 2010, 2018.

A look at the figure shows that imports of "machinery and transport and equipment" continue to predominate so also imports of "manufactured goods capital goods" continue to significantly gain momentum.

We can make some preliminary implications for the Free Trade Agreement effects. It is clear that trade in "machines, transport and equipment" and "fuel" are of significant importance between Nigeria and China. This could be a pointer of a strong degree of Intraindustry trade which could mean that removal of trade barriers would allow further buttress this type of trade. This is however not as easy as one thinks for many factors come into play to determine trade. Given the literature we can explain the importance of these two important commodities for the growth of the two economies. we can however opine that the manufacturing, capital goods and commodity (fuel) trade will be most affected should a free trade agreement between Nigeria and China be signed or trade on the two key items be facilitated.

Overall we note similarities of the trade between Nigeria and China. This needs to be further investigated using the indices before concluding that the formation of a FTA could born large trade effects.

Computation of the Revealed Comparative Advantages (RCA)

Table 3. Revealed Comparative Advantages (RCA) results.

\begin{tabular}{llll}
\hline Product Code & Trade Value in US\$1000 & \%of Total Share & Revealed Fuel Comparative Advantage \\
\hline 01-05_Animal & 176.32 & 0.01 & 0 \\
06-15_Vegetable & $54,506.40$ & 3.27 & 0.79 \\
16-24_FoodProd & $1,353.70$ & 0.08 & 0.05 \\
25-26_Minerals & $24,959.75$ & 1.5 & 0.19 \\
27-27_Fuels & $1,539,757.70$ & 92.48 & 10.77 \\
28-38_Chemicals & 508.77 & 0.03 & 0 \\
39-40_PlastiRub & $12,714.54$ & 0.76 & 0.16 \\
41-43_HidesSkin & $2,275.37$ & 0.14 & 0.31 \\
44-49_Wood & 150.7 & 0.01 & 0 \\
50-63_TextCloth & 219.88 & 0.01 & 0.01 \\
72-83_Metals & $5,835.12$ & 0.35 & 0.08 \\
84-85_MachElec & 398.85 & 0.02 & 0 \\
86-89_Transport & $21,973.91$ & 1.32 & 0.23 \\
90-99_Miscellan & 198.54 & 0.01 & 0 \\
\hline
\end{tabular}

Source: Author's computation, 2020.

Exports displaying the highest share tend to be in sectors experiencing comparative advantages. The table 3 above shows that exports of fuels has the highest Revealed Comparative Advantages (RCA) 10.77 compared with textiles/clothing (0.01) with the least RCA. This is an indication that Nigeria is exporting products with a comparative advantage to China.

Now let see China exports to Nigeria with a view to assessing the comparative advantage and competitiveness of the products in view. 
Table 4. Revealed Comparative Advantages of China.

\begin{tabular}{llll}
\hline Product Code & Trade Value in US\$1000 & \% of Total China & Revealed Comparative Advantage \\
\hline 01-05_Animal & $41,828.37$ & 0.25 & 0.11 \\
06-15_Vegetable & $15,751.35$ & 0.09 & 0.03 \\
16-24_FoodProd & $207,850.96$ & 1.25 & 0.31 \\
25-26_Minerals & $6,581.09$ & 0.04 & 0.24 \\
27-27_Fuels & $192,200.96$ & 1.16 & 0.06 \\
28-38_Chemicals & $955,726.95$ & 5.75 & 0.67 \\
39-40_PlastiRub & $1,186,215.35$ & 7.13 & 1.3 \\
41-43_HidesSkin & $110,783.18$ & 0.67 & 2.46 \\
44-49_Wood & $446,342.80$ & 2.68 & 1.32 \\
50-63_TextCloth & $4,053,764.11$ & 24.37 & 2.3 \\
64-67_Footwear & $973,153.59$ & 5.85 & 2.39 \\
68-71_StoneGlas & $475,560.96$ & 2.86 & 1.85 \\
72-83_Metals & $2,297,441.50$ & 13.81 & 1.91 \\
84-85_MachElec & $3,692,570.64$ & 22.2 & 1.15 \\
86-89_Transport & $1,236,866.72$ & 7.44 & 0.86 \\
90-99_Miscellan & $741,435.04$ & 4.46 & 1.32 \\
\hline
\end{tabular}

A look at the table 4 above shows that China has a revealed comparative advantages of exporting "textiles and clothing" materials based on the highest RCA share value.

We can next assess the type of trade between two blocks by using Intra Industry Trade indices.

\subsection{Interpreting of the Intra Trade Indices}

According to the literature classical measure of IIT was introduced by Grubel and Lloyd (1975) and bears the authors names (GL index). Thus the equation below summarizes IIT model:

$$
G L_{i j k}=1-\frac{\left|X_{i j k}-M_{i j k}\right|}{\left(X_{i j k}+M_{i j k}\right)}
$$

where $X_{i j k}$ is exports from country $\mathrm{i}$ to country $\mathrm{j}$ of commodity $\mathrm{k}$, and $\mathrm{M}$ corresponds to imports with the same subscript. $k$ is defined at the level of aggregation. IIT).

The index ranges in value from 0 (no IIT) to 1 (all trade

We first of all compute the IIT indices for all 6-digit traded categories and then aggregate up to find a number that captures the current levels of IIT.

Table 5. Evolution of intra-industry trade (averages), 2000, 2010 and 2015.

\begin{tabular}{llll}
\hline & GL & Horizontal IIT & Vertical IIT \\
\hline 2000 & 0.32620425 & 0.22383487 & 0.35432129 \\
2000 & 0.33094453 & 0.35720862 & 0.40137357 \\
2005 & 0.34418411 & 0.38718675 & 0.43424703 \\
\hline
\end{tabular}

Source: Author's computation,2020.

Table 5 above presents the of IIT. It shows that IIT is very low suggesting a little evidence of deep economic integration between Nigeria and China. Since the integration is low between the two countries, the scope is equally low. Thus promoting integration through trade reform between Nigeria and China is fundamental.

\section{Conclusion}

The top two countries to which Nigeria imported goods
2018 along with the share in percentage are

1) Nigeria imports from China worth US\$ 8,349 million, with a partner share of 19.41 percent.

2) Nigeria imports from Netherlands worth US $\$ 4,906$ million, with a partner share of 11.41 percent.

The top two imported HS 6 digit level products from world by Nigeria along with trade value are

1) Nigeria imported Petroleum oils, etc, (excl. crude); preparation, worth US\$12,489,419.32 million.

2) Nigeria imported Floating or submersible drilling or production, worth US\$ $3,851,708.72$ million.

The top five exported HS 6 digit level products to world by Nigeria along with trade value are:

1) Nigeria exported Petroleum oils and oils obtained from bituminous, worth US\$ 51,371,239.56 million.

2) Nigeria exported Natural gas, liquefied, worth US\$ 6,150,794.49 million.

3) Nigeria exported Tugs and pusher craft, worth US\$ 1,198,341.30 million.

4) Nigeria exported Petroleum gases and other gaseous hydrocarbons, worth US\$424,718.01 million.

5) Nigeria exported Cocoa beans, whole or broken, raw or roasted, worth US\$302,055.99 million

The top five imported HS 6 digit level products from world by Nigeria along with trade value are

1) Nigeria imported Petroleum oils, etc, (excl. crude); preparation, worth US\$12,489,419.32 million.

2) Nigeria imported Floating or submersible drilling or production, worth US\$ $3,851,708.72$ million.

3) Nigeria imported Durum wheat, worth US\$ 1,321,039.47 million.

4) Nigeria imported Automobiles with diesel engine displacing more, worth US\$ 826,888.02 million.

5) Nigeria imported Motorcycles with reciprocating piston engine di, worth US\$ 677,113.15 million

Establishing a regional trade agreement between Nigeria and China have welfare impacts on both countries and all will benefit from economic trade ties. 


\section{References}

[1] Baldwin, R., and Wyplosz, C., (2006), The Economics of European Integration, McGraw-Hill Education.

[2] Dasgupta, R., and Panagariya, A., (2002), "Free Trade Areas and Rules of Origin: Economics and Politics", Working Paper.

[3] Cecchini, P., Catinat, M., and Jacquemin, A., (1988), The European Challenge 1992: The Benefits of the Single Market, Gower.

[4] Evans, D., Gasiorek, M., Ghoneim, A., Haynes-Prempeh, M., Holmes, P., Iacovone, L., Jackson, K., Iwanow, T., Robinson, S., and Rollo, J., (2006), Assessing Regional Trade Agreements with Developing Countries: Shallow And Deep Integration, Trade, Productivity, and Economic Performance, Study for DFID, CARIS, University of Sussex, published online at: http://www.sussex.ac.uk/Units/caris/CARIS/DFIFRTA-REPORT.pdf.

[5] Gasiorek, M., Smith, A., and Venables, A., (2002), "The Accession of the UK to the EC: A Welfare Analysis Journal of Common Market Studies.", Vol. 40, No. 3, September 2002, pp. 425-447 (23).

[6] Grossman, G., and Helpman, E., (1995), "The Politics of FreeTrade Agreements.", The American Economic Review, Vol. 85 , No. 4, September 1995, pp. 667-690.

[7] Grubel, H., and Lloyd, P., (1975), Intra Industry trade: The Theory and Measurement of International Trade in Differentiated Products, Wiley, New York.

[8] Humphrey, J., Schmitz, H., (2002), "How does insertion in global value chains affect upgrading in industrial clusters?", Regional Studies, Vol. 36, No. 9, December 2002, pp. 10171027 (11).

[9] Cox, D., and Harris, R., (1992), "North American Free Trade and Its Implications for Canada: Results from a CGE Model of North American Trade.", The World Economy, Vol. 15, No. 1, pp. 31-44.

[10] Krugman, P., and Venables, A., (1995), "Globalization and the Inequality of Nations.", The Quarterly Journal of Economics, MIT Press, Vol. 110, No. 4, November 1995, pp. 857-80.

[11] La Nasa III, J., (1996), "Rules of Origin and the Uruguay Round's Effectiveness in Harmonizing and Regulating them.", The American Journal of International Law, Vol. 90, No. 4, October 1996, pp. 625-640.

[12] Smith, A., and Venables, A., (1988), "Completing the Internal Market in the European Community: Some Industry Simulations", European Economic Review, No. 32, pp. 15011525.

[13] United Nations Statistics Division Commodity Trade Statistics Database (UNSD COMTRADE), published online at: http://comtrade.un.org.

[14] United Nations Conference on Trade and Development (UNCTAD), and World Bank (WB), World Integrated Trade Solution (WITS), published online at: http://wits.worldbank.org/package/WITS-Install-XP.htm.

[15] Winters, L., (1985), "Separability and the Modelling of International Economic Integration: U.K. Exports to Five Industrial Countries", European Economic Review, Vol. 27, No. 3, pp. 335-353. 